\title{
IMP3 overexpression occurs in various important cancer types and is linked to aggressive tumor features: A tissue microarray study on 8,877 human cancers and normal tissues
}

\author{
CHRISTOPH BURDELSKI $^{1 *}$, NILOFAR JAKANI-KARIMI ${ }^{2 *}$, FRANK JACOBSEN ${ }^{2}$, \\ CHRISTINA MÖLLER-KOOP ${ }^{2}$, SARAH MINNER ${ }^{2}$, RONALD SIMON ${ }^{2}$, GUIDO SAUTER ${ }^{2}$, \\ STEFAN STEURER $^{2}$, TILL S. CLAUDITZ ${ }^{2}$ and WALDEMAR WILCZAK ${ }^{2}$ \\ ${ }^{1}$ General, Visceral and Thoracic Surgery Department and Clinic, University Medical Center Hamburg-Eppendorf; \\ ${ }^{2}$ Institute of Pathology, University Medical Center Hamburg-Eppendorf, Hamburg, Germany
}

Received May 16, 2017; Accepted September 24, 2017

DOI: $10.3892 /$ or.2017.6072

\begin{abstract}
IMP3 is an RNA binding protein required for ribosomal RNA processing, which has been suggested to be a prognostic marker in a large variety of human types of cancer. However, available data on the prevalence of IMP3 expression are largely discrepant. To systematically investigate the epidemiology and clinical relevance of IMP3 expression in human cancers we employed a two-step tissue microarrays (TMAs) approach. First, a normal tissue TMA and a multi-tumor TMA were analyzed for immunohistochemically detectable expression of IMP3 in 76 different normal tissue types and 3889 cancer samples from 95 different tumor categories. In a second step, we searched for associations between IMP3 expression and tumor phenotype and patient prognosis in TMAs containing 697 urinary bladder cancers, 1711 colon cancers, 343 esophageal adenocarcinomas, 251 esophageal squamous cell cancers, 673 lung cancers), 275 pancreatic cancers and 230 stomach cancers. In normal tissues, unequivocal IMP3 expression was found in placenta, lymphocytes and some types of glandular epithelial cells. In cancers, at least one case with weak expression could be found in 76 out of 95 $(80 \%)$ different tumor types and 64 entities $(67 \%)$ had at least one tumor with strong positivity. IMP3 expression was most frequently found in testicular cancer (including 71\% seminomas and $96 \%$ non-seminomas), neuroblastoma (88\%), and squamous cell cancer of various origins. Significant associations were found between IMP3 and adverse tumor features
\end{abstract}

Correspondence to: Dr Ronald Simon, Institute of Pathology, University Medical Center Hamburg-Eppendorf, Martinistrasse 52, D-20246 Hamburg, Germany

E-mail:r.simon@uke.de

*Contributed equally

Key words: IMP3, multi-tumor tissue microarray, normal tissue, immunohistochemistry in esophageal adenocarcinomas and cancers of the urinary bladder, lung, stomach, and pancreas. In summary, IMP3 was frequently expressed in many different tumor types, and was typically associated with aggressive tumor features.

\section{Introduction}

Insulin-like growth factor II m-RNA-binding protein 3 (IMP3) is a member of the IMP family playing an important role in cell migration in early embryogenesis $(1,2)$. This 'U3 small nucleolar ribonucleoprotein' is a component of an RNA binding protein required for the early cleavage during pre-18s ribosomal RNA processing. Previously, IMP3 has gained considerable interest as a cancer-associated protein. IMP3 overexpression has been reported in a variety of human types of cancer, including lung cancer (3), germ cell cancer (4), colon cancer (5), pancreatic cancer (6), gastric cancer (7), liver cancer (8), and kidney cancer (9), and has been linked to advanced disease stage and adverse clinical outcome in some of these cnacers $(5,7,8,10-12)$. Collectively, these studies strongly suggest that IMP3 may represent a valuable prognostic marker in human cancer. However, as the number of studies suggesting biological and clinical relevance of IMP3 is rapidly increasing, there are also a growing number of reports revealing considerable discrepancies with respect to the frequency of expression in various types of cancer. For example, reported frequencies in IMP3 expression ranges from 0 to $83 \%$ in prostate cancer (13-16), from 11 to $86 \%$ in papillary thyroid cancer (17-20), from 11 to $65 \%$ in papillary renal cell cancer $(9,12)$, from 0 to $52 \%$ in leiomyoma $(21,22)$, from 21 to $71 \%$ in invasive urinary bladder tumor $(23,24)$, from 50 to $100 \%$ in small cell lung cancer $(3,25)$, and from 37 to $83 \%$ in malignant mesothelioma $(26,27)$. Such discrepancies may be due to the use of different antibodies, staining protocols, and scoring criteria in these studies. The optimal study for assessing the relative importance of a potentially relevant molecule across tumor types includes the analysis of as large a number of different normal tissues, cancer types and subtypes as possible, followed by the evaluation of the clinical value of IMP3 in selected types of cancer with 
frequent IMP3 expression. Moreover, it would be necessary to ensure a maximal standardization of all these analyses. Tissue microarray (TMA) technology is a suitable tool for such a study, as a large number of tissues can be analyzed on few sections that are cut in 1 day and that can be stained in 1 day in a set of reagents under completely identical staining conditions.

In this study, we utilized a two-step tissue microarray (TMA) approach to evaluate the clinical utility of IMP3 testing in human normal tissues and cancer. In a first step, we screened 76 different normal tissue types and samples of 95 different tumor types using a multi-tumor TMA. In a second step, tumor-type specific TMAs with clinical follow-up data were utilized to evaluate the clinical significance of IMP3 alterations in five selected tumor entities. Our approach implicated frequent IMP3 expression in 76 different tumor types and concomitantly demonstrated the association between IMP3 expression and poor prognosis in adenocarcinomas of the lung.

\section{Materials and methods}

Human tissues. The construction of tissue microarrays was as reviously described (28). The normal tissue TMA was composed of 8 samples each of 76 different normal tissue types (608 samples on one slide). The multi-tumor TMA contained 3,899 primary tumors from 95 different tumor types and subtypes distributed among 10 different TMA blocks each containing between 350 and 680 samples. The exact composition of this TMA is presented in Table I. In addition, six different prognosis TMAs were analyzed, representing 697 urinary bladder cancers (694 with clinical follow-up data), 1711 colon cancers (1709 with clinical follow-up data), 343 esophageal adenocarcinomas (300 with clinical follow-up data), 251 esophageal squamous cell cancers (244 with clinical follow-up data), 673 lung cancers (269 with clinical followup data), 275 pancreatic cancers (219 with clinical follow-up data), and 230 stomach cancers (146 with clinical follow-up data). The composition of these TMAs has been described before (29-33). No informed consent was obtained in accordance with the local law (HmbKHG, §12,1).

Immunohistochemistry. Freshly cut TMA sections were analyzed. IMP3 expression was detected with a monoclonal mouse anti-human antibody (clone 69.1; Dako M3626, Glostrup, Denmark) in a dilution of 1:100 after peroxidase blocking with $\mathrm{H}_{2} \mathrm{O}_{2}$ (Dako S2023) for $10 \mathrm{~min}$. High-temperature pretreatment of slides was carried out in an autoclave with citrate buffer, pH 9.0 for 5 min. The Envision system (Dako 5007) was used to visualize the staining. In normal tissues, a cell type specific distribution of IMP3 expression was recorded, and the staining intensity was estimated as weak $(+)$, moderate $(++)$, or strong (+++). In tumor tissues, cytoplasmic staining was evaluated by staining intensity $(0,1+, 2+$, and $3+)$, and the fraction of positive tumor cells was scored for each tissue spot. A final score was built from these two parameters according to the following criteria: negative scores had a staining intensity of 0 and $1+$ in $\leq 10 \%$ of tumor cells; weak scores had a staining intensity of $1+$ in $>10 \%$ and $\leq 70 \%$ of tumor cells or a staining intensity of $2+$ in $\leq 30 \%$ of tumor cells; moderate scores had a staining intensity of $1+$ in $>70 \%$ of tumor cells, a staining intensity of $2+$ in $>30 \%$ and $\leq 70 \%$ of tumor cells or a staining intensity of $3+$ in $\leq 30 \%$ of tumor cells; and strong scores had a staining intensity of $2+$ in $>70 \%$ of tumor cells or a staining intensity of $3+$ in $>30 \%$ of tumor cells. All tumors exhibiting at least weak expression were defined as IMP3-positive.

Statistical analysis. For statistics, JMP ${ }^{\circledR} 12.0$ software (SAS institute Inc., Cary, NC, USA) was used. All P-values were two-sided, and P-values $<0.05$ were considered as significant. To study the relationship between IMP3 expression and clinicopathological parameters, contingency table analysis and Chi-square test (likelihood) were used. Analysis on recurrence-free and overall survival was performed using the Kaplan-Meier method and was compared via log-rank test. Cox regression and multivariate analyses were used to assess independence of IMP3 staining.

\section{Results}

IMP3 protein expression in normal tissues. Positive IMP3 staining was seen in few normal tissues and in specific cell types only, including amnion $(+)$, chorion cells $(+)$ syncytiotrophoblast $(+++)$, cytotrophoblast $(+++)$, decidua $(+)$ and mesenchymal cells $(++)$ of the placenta, lymph follicles in lymph nodes and tonsils (lymphoblasts $(+++)$, lymphocytes $(+++)$, thymocytes $(+)$, absorptive cells of the ileum $(+++)$, crypt cells of rectal mucosa $(+)$, mucus cells $(++)$ of submandibular and sublingual glands, spermatogonia of the testis $(++)$, ciliated cells $(+)$ of bronchial mucosa, mucinous acinar cells of bronchial glands $(++)$, secretory cells of the endocervix $(+)$, ciliated cells of the fallopian tube $(+++)$, and cells of the adenohypophysis of the anterior lobe of the pituitary gland (+).

Normal tissue samples that were also analyzed but did not exhibit any IMP3 staining included: aorta, heart, striated muscle, tongue, uterus, appendix, esophagus, stomach, ileum muscle, colon, kidney, urinary bladder, penis, ovary, fat, skin, lip, oral cavity, anal canal, ectocervix, spleen, duodenum, gallbladder, liver, pancreas, parotid gland, bone marrow, prostate, seminal vesicles, epididymis, nose sinus, lung, breast, adrenal gland, parathyroid gland, thyroid gland, cerebellum and cerebrum.

IMP3 protein expression in tumors. Analyzable results could be obtained from 96 of the 99 types of cancer represented in our multi-tumor TMA. At least weak IMP3 protein expression could be detected in $76(80 \%)$ of the 95 tumor categories with analyzable results, including 64 (67\%) categories where at least one tumor revealed a strong positivity. The immunohistochemical results are summarized in Table I. IMP3 positivity was most striking in testicular cancers, where all examined tumors exhibited positive staining, including $71 \%$ (seminomas) and $96 \%$ (non-seminomas) with strong staining. Additional cancers with frequent IMP3 positivity included Hodgkin's lymphomas (90\%), neuroblastomas ( $88 \%$ positive), squamous cell cancers of various origins, e.g. of the lungs $(81 \%)$, oral cavity $(73 \%)$, esophagus $(71 \%)$, larynx $(67 \%)$, penis $(59 \%)$, and skin $(50 \%)$, as well as adenocarcinomas of the esophagus $(74 \%)$, pancreas $(62 \%)$, cervix $(58 \%)$, stomach $(50-55 \%)$, and lungs (51\%). In contrast, IMP3 staining was only rarely 
Table I. Summary of IMP3 immunohistochemical findings in 95 human types of cancer.

IMP3 IHC results

Tumor entity

On TMA Analyzable

(n)

(n)

Negative Weak Moderate Strong

Skin tumors

Skin, Merkel cell carcinoma

Skin, malignant schwannoma

Skin, squamous cell cancer

Skin, malignant melanoma

Pleomorphic sarcoma, NOS

Pilomatrixoma

Basalioma

Benign naevus

Skin, dermatofibrosarcoma protuberans

Lung tumors

Lung, squamous cell cancer

Larynx, squamous cell cancer

Lung, large cell cancer

Lung, adenocarcinomas

Lung, malignant mesothelioma

Pharynx lymphoepithelial ca.

Lung, small cell lung cancer

Lung bronchioalveolar cancer

59

57

48

71

28

5

15

15

Gynecological tumors

Cervix, adenosquamous ca.

Cervix, squamous cell carcinoma

Cervix, adenocarcinoma

Ovary, mucinous cancer

Ovary, serous cancer

Ovary, mullerian mixed type tumor

Ovary, endometrioid cancer

Uterus endometrial cancer

Vulva, squamous cell cancer

Granular cell tumor

Leiomyosarcoma

Ovary, Brenner

Mammary, apocrine type cancer

Mammary, medullary type cancer

Mammary, ductal type cancer

Mammary, lobular type cancer

Mammary, mucinous type cancer

Mammary, tubular type cancer

Mammary, cribriform type cancer

Mammary, phylloid type tumor

Uterus stromasarcoma

Uterus leiomyoma

Gastrointestinal tumors and head and neck tumors

Esophagus, adenocarcinoma

Mouth, squamous cell cancer

Esophagus, squamous cell ca.

Pancreas, adenoca. ampulla

Pancreas, ductal adenocarcinoma

Intestinal cancer

Stomach, diffuse type cancer

Stomach, intestinal type cancer

Gallbladder cancer

Colon cancer

$\begin{array}{rr}6 & \\ 14 & 1 \\ 51 & 4 \\ 37 & 2 \\ 25 & 19 \\ 48 & 2 \\ 67 & 3 \\ 59 & 35 \\ 5 & \end{array}$

1
11
40
26
19
24
39
35
4

$0 \%$
$36 \%$
$50 \%$
$54 \%$
$74 \%$
$75 \%$
$79 \%$
$97 \%$
$100 \%$

$100 \%$
$0 \%$
$10 \%$
$0 \%$
$0 \%$
$17 \%$
$8 \%$
$3 \%$
$0 \%$

$\begin{array}{rr}0 \% & 0 \% \\ 18 \% & 45 \% \\ 20 \% & 20 \% \\ 8 \% & 38 \% \\ 0 \% & 26 \% \\ 4 \% & 4 \% \\ 8 \% & 5 \% \\ 0 \% & 0 \% \\ 0 \% & 0 \%\end{array}$

37
39
21
39
6
4
2
8

\section{$19 \%$}

$33 \%$

$43 \%$

$$
49 \%
$$

$50 \%$

\section{$50 \%$}

\section{$50 \%$}

$63 \%$

$19 \%$

$14 \%$

\section{$13 \%$}

$0 \%$

$18 \%$

$0 \%$

$0 \%$

$0 \%$

$0 \%$

\section{$33 \%$}

$62 \%$

$$
42 \%
$$

$41 \%$

\section{$55 \%$}

$57 \%$

$67 \%$

$67 \%$

$73 \%$

$80 \%$

$88 \%$

93\%

$67 \%$

$76 \%$

93\%

$100 \%$

$100 \%$

$100 \%$

$100 \%$

$100 \%$

$100 \%$

$100 \%$

\section{$33 \%$}

$19 \%$

$21 \%$

$16 \%$

$9 \%$

$0 \%$

$11 \%$

$14 \%$

$16 \%$

$20 \%$

$0 \%$

$0 \%$

$0 \%$

$7 \%$

$3 \%$

$0 \%$

$0 \%$

$0 \%$

$0 \%$

$0 \%$

$0 \%$

$0 \%$

$0 \% \quad 0 \%$

$\begin{array}{ll}60 & 19\end{array}$

$16 \%$ 
Table I. Continued. Summary of IMP3 immunohistochemical findings in 95 human types of cancer.

\begin{tabular}{|c|c|c|c|c|c|c|}
\hline \multirow[b]{2}{*}{ Tumor entity } & \multirow{2}{*}{$\begin{array}{l}\text { On TMA } \\
\text { (n) }\end{array}$} & \multirow{2}{*}{$\begin{array}{l}\text { Analyzable } \\
\text { (n) }\end{array}$} & \multicolumn{4}{|c|}{ IMP3 IHC results } \\
\hline & & & Negative & Weak & Moderate & Strong \\
\hline \multicolumn{7}{|c|}{ Gastrointestinal tumors and head and neck tumors } \\
\hline Anal cancer & 18 & 7 & $57 \%$ & $29 \%$ & $14 \%$ & $0 \%$ \\
\hline Colon, high grade adenoma & 40 & 15 & $60 \%$ & $33 \%$ & $7 \%$ & $0 \%$ \\
\hline Hepatocellular carcinoma & 55 & 23 & $61 \%$ & $4 \%$ & $4 \%$ & $30 \%$ \\
\hline Warthin tumor & 57 & 39 & $79 \%$ & $18 \%$ & $3 \%$ & $0 \%$ \\
\hline Parotid gland, mucoepidermoid ca. & 46 & 16 & $81 \%$ & $0 \%$ & $0 \%$ & $19 \%$ \\
\hline Colon, low grade adenoma & 56 & 19 & $89 \%$ & $5 \%$ & $0 \%$ & $5 \%$ \\
\hline Basal cell adenoma & 37 & 22 & $95 \%$ & $0 \%$ & $0 \%$ & $5 \%$ \\
\hline GIST & 46 & 40 & $100 \%$ & $0 \%$ & $0 \%$ & $0 \%$ \\
\hline Parotid gland, pleomorphic adenoma & 61 & 30 & $100 \%$ & $0 \%$ & $0 \%$ & $0 \%$ \\
\hline Pancreas, neuroendocrine ca. & 20 & 5 & $100 \%$ & $0 \%$ & $0 \%$ & $0 \%$ \\
\hline \multicolumn{7}{|l|}{ Genitourinary tract tumors } \\
\hline Testis, seminoma & 92 & 69 & $0 \%$ & $13 \%$ & $16 \%$ & $71 \%$ \\
\hline Testis, non-seminoma & 45 & 25 & $0 \%$ & $4 \%$ & $0 \%$ & $96 \%$ \\
\hline Teratoma & 60 & 15 & $13 \%$ & $7 \%$ & $13 \%$ & $67 \%$ \\
\hline Oncocytoma & 62 & 9 & $33 \%$ & $22 \%$ & $11 \%$ & $33 \%$ \\
\hline Penis, squamous cell cancer & 46 & 22 & $41 \%$ & $18 \%$ & $14 \%$ & $27 \%$ \\
\hline Urinary bladder, $\mathrm{T} 2-\mathrm{T} 4$ tumors & 60 & 56 & $61 \%$ & $11 \%$ & $4 \%$ & $25 \%$ \\
\hline Urinary bladder, Ta-Tumors & 62 & 57 & $98 \%$ & $2 \%$ & $0 \%$ & $0 \%$ \\
\hline Kidney chromophobic & 56 & 9 & $67 \%$ & $11 \%$ & $0 \%$ & $22 \%$ \\
\hline Kidney, papillary & 31 & 8 & $75 \%$ & $0 \%$ & $0 \%$ & $25 \%$ \\
\hline Kidney, clear cell cancer & 68 & 45 & $96 \%$ & $2 \%$ & $0 \%$ & $2 \%$ \\
\hline Prostate cancer & 63 & 44 & $100 \%$ & $0 \%$ & $0 \%$ & $0 \%$ \\
\hline \multicolumn{7}{|l|}{ Neuroendocrine tumors } \\
\hline Adrenal gland carcinoma & 8 & 6 & $83 \%$ & $0 \%$ & $0 \%$ & $17 \%$ \\
\hline Adrenal gland adenoma & 21 & 19 & $89 \%$ & $5 \%$ & $0 \%$ & $5 \%$ \\
\hline Thyroid, anaplastic cancer & 3 & 1 & $0 \%$ & $0 \%$ & $0 \%$ & $100 \%$ \\
\hline Thyroid, medullary cancer & 28 & 6 & $17 \%$ & $0 \%$ & $0 \%$ & $83 \%$ \\
\hline Thyroid, papillary cancer & 54 & 15 & $87 \%$ & $13 \%$ & $0 \%$ & $0 \%$ \\
\hline Thyroid, follicular cancer & 47 & 10 & $90 \%$ & $0 \%$ & $0 \%$ & $10 \%$ \\
\hline Thyroid, adenoma & 65 & 22 & $91 \%$ & $0 \%$ & $0 \%$ & $9 \%$ \\
\hline Paraganglioma & 36 & 29 & $93 \%$ & $0 \%$ & $0 \%$ & $7 \%$ \\
\hline Pheochromocytoma & 64 & 48 & $100 \%$ & $0 \%$ & $0 \%$ & $0 \%$ \\
\hline \multicolumn{7}{|l|}{ Nervous system tumors } \\
\hline Neuroblastoma & 51 & 26 & $12 \%$ & $4 \%$ & $8 \%$ & $77 \%$ \\
\hline Astrocytoma & 48 & 6 & $50 \%$ & $17 \%$ & $0 \%$ & $33 \%$ \\
\hline Oligodendriglioma & 28 & 7 & $86 \%$ & $0 \%$ & $14 \%$ & $0 \%$ \\
\hline Medulloblastoma & 4 & 2 & $100 \%$ & $0 \%$ & $0 \%$ & $0 \%$ \\
\hline Ependymoma & 10 & 1 & $100 \%$ & $0 \%$ & $0 \%$ & $0 \%$ \\
\hline \multicolumn{7}{|l|}{ Soft-tissue tumors } \\
\hline Chondrosarcoma & 5 & 2 & $50 \%$ & $0 \%$ & $0 \%$ & $50 \%$ \\
\hline Angiosarcoma & 7 & 5 & $60 \%$ & $0 \%$ & $20 \%$ & $20 \%$ \\
\hline Liposarcoma & 16 & 14 & $86 \%$ & $0 \%$ & $7 \%$ & $7 \%$ \\
\hline Neurofibroma & 60 & 21 & $100 \%$ & $0 \%$ & $0 \%$ & $0 \%$ \\
\hline Desmoid tumor & 9 & 9 & $100 \%$ & $0 \%$ & $0 \%$ & $0 \%$ \\
\hline Synovia, giant cell carcinoma & 40 & 9 & $100 \%$ & $0 \%$ & $0 \%$ & $0 \%$ \\
\hline Hemangiopericytoma & 7 & 5 & $100 \%$ & $0 \%$ & $0 \%$ & $0 \%$ \\
\hline \multicolumn{7}{|l|}{ Lymphatic tumors } \\
\hline Lymphoma, Hodgkin & 43 & 10 & $10 \%$ & $0 \%$ & $90 \%$ & $0 \%$ \\
\hline Thymoma & 57 & 43 & $98 \%$ & $0 \%$ & $0 \%$ & $2 \%$ \\
\hline
\end{tabular}

${ }^{a}$ Analyzable refers to tumor cells containing spots on the tissue microarray. 


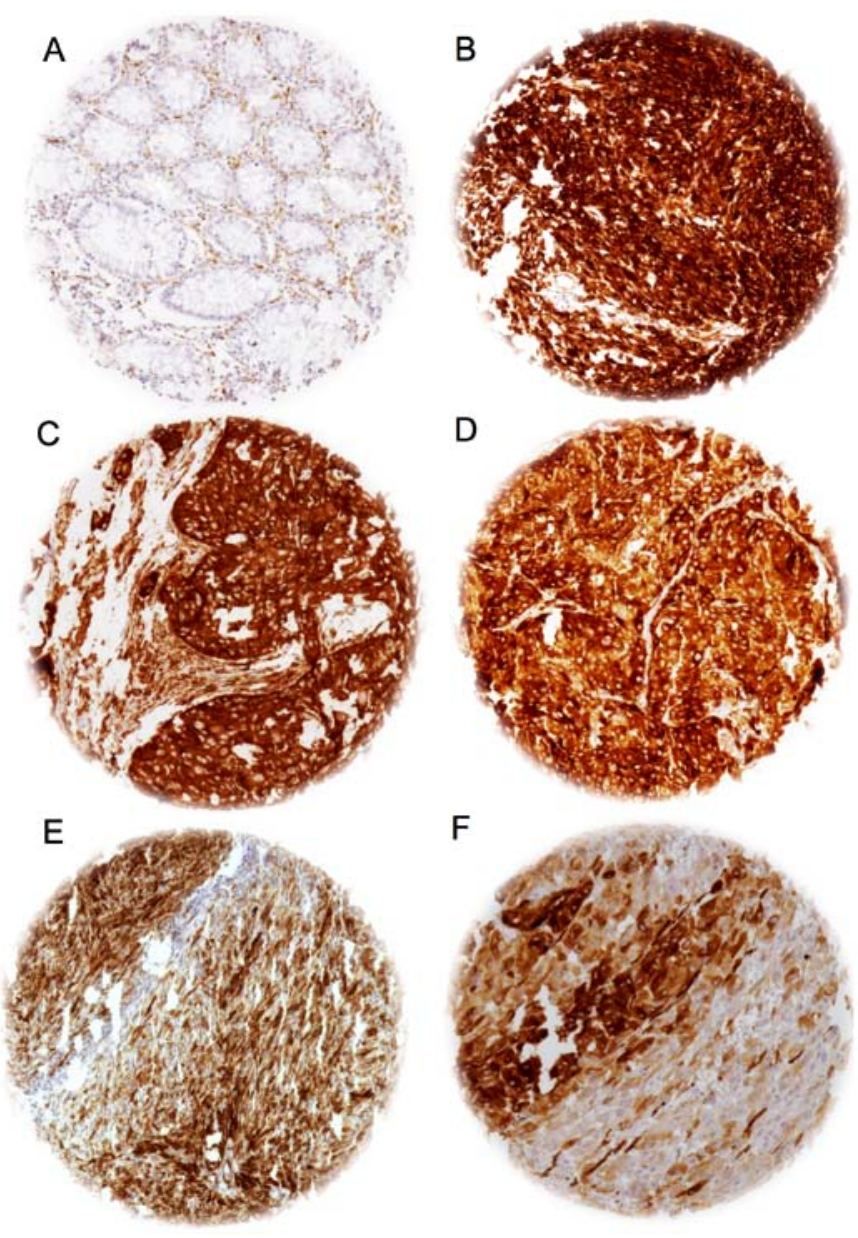

Figure 1. Examples of IMP3 staining in a case of (A) normal kidney tissue, (B) placenta, (C) seminoma, (D) non-seminoma (E) pancreatic cancer and (F) Hodgkin lymphoma.

found in breast cancers of no special type (7\%) and clear cell renal cell cancers (4\%). Examples of immunostaining of IMP3 positive and negative tissues are presented in Fig. 1.

The tumor types where IMP3 protein expression could never be detected included dermatofibrosarcomas of the skin ( 0 out of 4 ), subtypes of breast cancers (including lobular, mucinous, tubular cancers and phylloid tumors, 0 out of 11-23), leiomyomas ( 0 out of 20$)$, stromal sarcomas ( 0 out of 2 ), GIST ( 0 out of 40), parotid adenomas ( 0 out of 30 ), neuroendocrine pancreatic cancers ( 0 out of 5$)$, prostate cancers ( 0 out of 44$)$, pheochromocytomas ( 0 out of 48 ), medulloblastomas ( 0 out of 2$)$, ependymomas ( 0 out of 1$)$, neurofibromas ( 0 out of 21 ), desmoid tumors ( 0 out of 9 ), synovial giant cell carcinomas (0 out of 9 ) and hemangiopericytomas ( 0 out of 5) and. However, the number of examined cases of several of these tumor types was low. These data therefore do not rule out that IMP3 expression can sometimes also occur in these tumor types.

Tumor type-specific prognostic TMAs. Expression data were available for 639 out of 697 (91.6\%) urinary bladder cancers, 1204 out of 1711 (70.4\%) colon cancers, 216 out of $343(63 \%)$ adenocarcinomas of the esophagus, 170 out of $251(67.7 \%)$ squamous cell carcinomas of the esophagus, 641 out of $763(84 \%)$ lung cancers, 280 of 358 (78.2\%) pancreas carcinomas, and 204 out of $230(88,7 \%)$ stomach cancers on the prognostic TMAs.

IMP3 positivity was found in $21.9 \%$ of urinary bladder cancers (strong: $7.4 \%$, moderate: $8.1 \%$, weak: $6.4 \%$ ), $63.4 \%$ of colon tumors (strong: $36 \%$, moderate: $16.6 \%$, weak: $10.7 \%$ ), $74.1 \%$ of esophageal adenocarcinomas (strong: $50.5 \%$, moderate: $11.1 \%$, weak: $12.5 \%$ ), $60.6 \%$ of esophageal squamous cell cancers (strong: $41.8 \%$, moderate: $8.2 \%$, weak: $10.6 \%$ ), $63.2 \%$ of lung cancers (strong: $47.1 \%$, moderate: $11.4 \%$, weak: $4.7 \%$ ) $48.9 \%$ of pancreatic cancers (strong: $8.2 \%$, moderate: $10.7 \%$, weak: $30 \%$ ), and $44.9 \%$ of stomach cancers (strong: $24 \%$, moderate: $10.8 \%$, weak: $20.1 \%$ ).

Significant associations were found between IMP3 and advanced stage and grade in urinary bladder cancers $(\mathrm{P}<0.0001$ each, Fig. 2A), in high grade and metastatic phenotype in esophageal adenocarcinomas ( $\mathrm{P} \leq 0.0025$, Fig. $2 \mathrm{~B})$, in a squamous cell phenotype in lung cancers $(\mathrm{P}<0.0001$, Fig. $2 \mathrm{C})$, and in shortened survival in adenocarcinomas of the lungs ( $\mathrm{P}=0.0175$, Fig. 2D), in stomach $(\mathrm{P}=0.0032$, Fig. 2E) and in pancreatic cancers ( $\mathrm{P}=0.0304$, Fig. $2 \mathrm{~F})$. No significant associations between IMP3 expression levels and patient prognosis were observed in urinary bladder cancers, squamous cell lung cancers and squamous cell esophageal cancers.

\section{Discussion}

The results of our study provide a comprehensive catalogue of IMP3 expression across a large variety of human types of cancer and subtypes. Our findings demonstrated that high levels of IMP3 protein expression were found in the vast majority of the analyzed types of cancer and underscored its considerable general importance in tumor biology. The novelty of this study is that staining was performed with a single antibody, in 1 laboratory on a large panel of different tumor entities on a single microarray.

The frequency of IMP3 expression in individual types of cancer is well in the range of that reported from previous research (Fig. 3), which corroborates the validity of our results. For example, virtually all analyzed testicular cancers; teratomas, Hodgkin's lymphomas and Merkel cell cancers of the skin were IMP3-positive under the experimental conditions selected for this study, which fits well with the $85-99 \%$ positivity reported in the literature (4,34-36). In contrast, and in concordance with previous research, tumor types largely lacking detectable IMP3 expression included breast cancers of no special type, gastrointestinal stromal tumors, desmoid tumors, benign naevi or leiomyomas, which all have been described as predominantly IMP3-negative before $(21,37,38)$. More variable findings with respect to published data were made in tumor types with intermediate IMP3-positivity, such as hepatocellular carcinomas (53-68\% in the literature; $40 \%$ in our study) or colon cancers (15-65\% in the literature; $47 \%$ in our study). It is obvious, that different antibodies and immunohistochemistry protocols, scoring criteria and the comparatively small number of samples (usually $<50$ per tumor category in our study) account for these differences.

There were 14 tumor types that were newly identified as having occasional IMP3 protein overexpression in this study. These included many important types of cancer such as squamous cell cancers of the vagina and vulva, medullary breast 

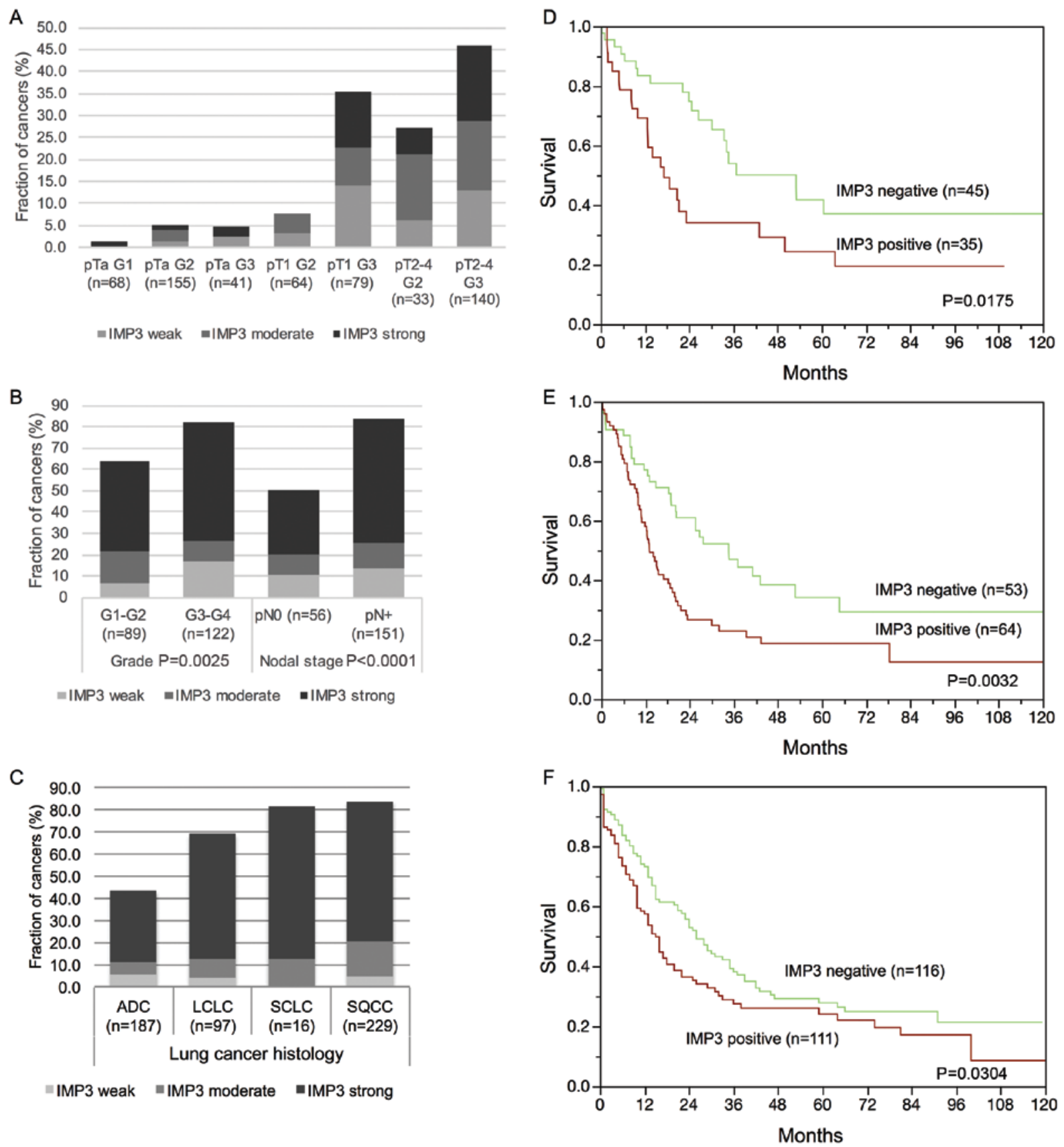

Figure 2. Associations between IMP3 staining results, tumor phenotypes and patient prognosis in different types of cancer. Association between IMP3 expression and (A) advanced tumor stage and high grade in urinary bladder cancer, (B) high grade and metastatic phenotype in esophageal adenocarcinomas, (C) squamous cell phenotype in lung cancer, (D) shortened survival in lung adenocarcinoma, (E) shortened survival in stomach cancer, and (F) shortened survival in pancreatic cancer.

and thyroid cancers, pharyngeal carcinomas, various sarcomas (including chondro-, angio- and liposarcomas), oncocytomas, as well as some types of neuronal cancers (e.g. paragangliomas and oligodendrigliomas). These findings further add to the growing list of IMP3-expressing types of cancer and emphasize the general role of IMP3 as a marker for malignant growth of tumors arising from epithelial, mesenchymal and neuronal tissues.

Since IMP3 is often referred to as a marker for distinguishing between benign and malignant lesions (39-43), it was of interest to also find at least occasional expression in a few individual cells of glandular epithelium, lymphatic tissues and placenta, which was in accordance to earlier studies demonstrating that
IMP3 was ubiquitously expressed in early developmental stages of human tissues but also in adult placenta $(44,45)$. In addition, we also found IMP3 expression in benign lesions such as Warthin's tumors, schwannomas, colon adenomas and basal cell adenomas. Such findings are often made in studies including multiple types of tumors and demonstrate that the specificity of molecular markers are often overestimated in initial studies including only a limited number of different samples. For example, IMP3 has been suggested to aid in the diagnosis of melanoma, leiomyosarcoma, HCC, papillary thyroid carcinoma, and follicular thyroid carcinomas, but it is not a sensitive marker for these tumors as lack of IMP3 expression in these tumors cannot exclude a malignant phenotype (reviewed in ref. 1). 


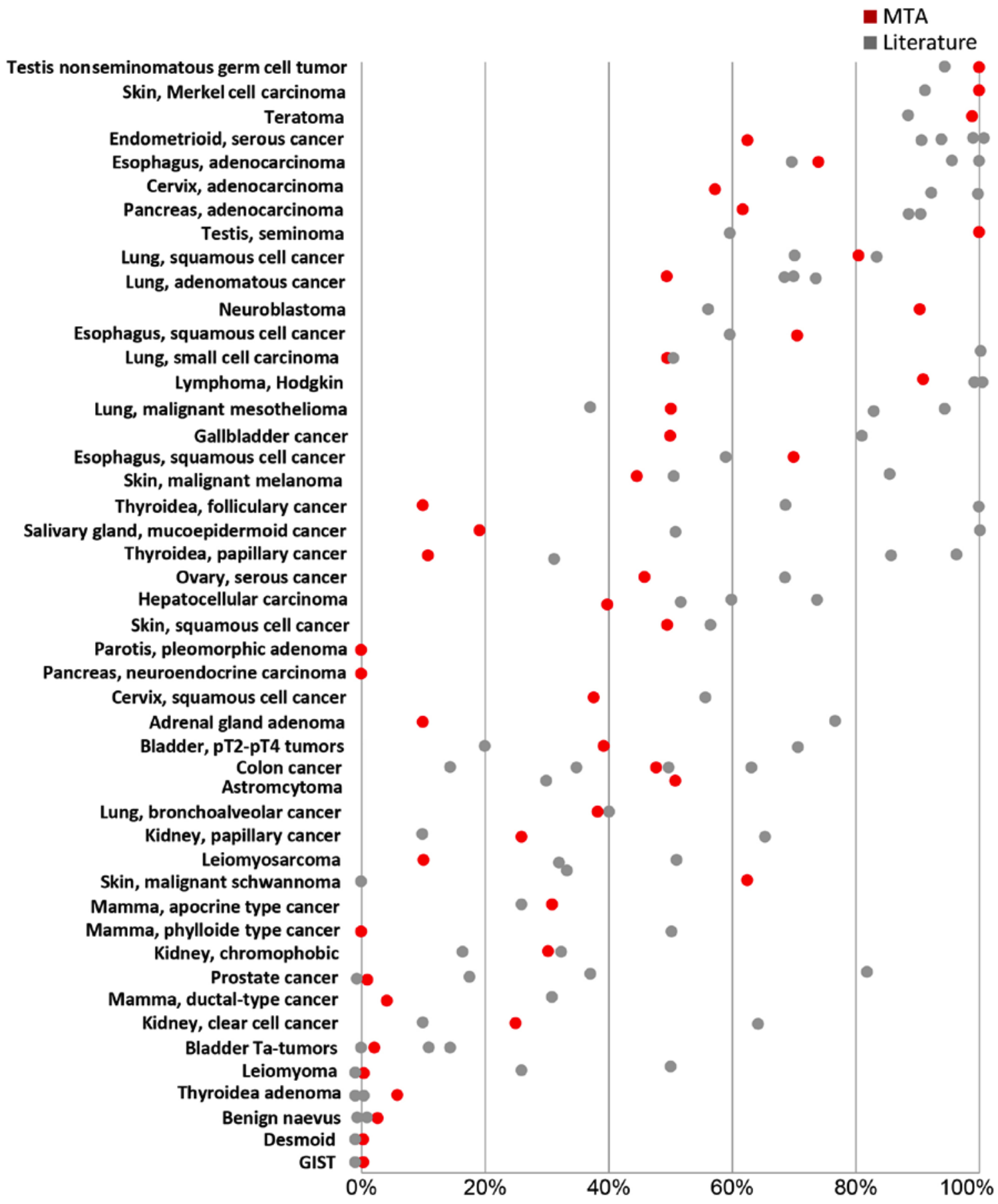

Figure 3. Summary of literature findings on the prevalence of IMP3 expression in human cancers: Red circles indicate the results of the current study. Findings from the literature $(4-6,8,9,12-27,34-37,42,46,48,62-95)$ sequence of citations equals the sequence of the tumor types from top to bottom) are marked by gray circles.

In addition to analyzing the molecular epidemiology of IMP3 expression, we took advantage of various pre-existing tumor type-specific prognostic TMAs for evaluation of the clinical significance of IMP3 expression in several tumor types. Urinary bladder, colon, esophageal, lung, pancreatic and stomach cancer were selected for follow-up studies because IMP3 was frequently positive in these tumor types and large TMAs were available. Significant associations between IMP3 expression and tumor phenotype as well as patient prognosis in our study further added to the knowledge on the clinical impact of IMP3 in these tumor types, which have been only studied in comparatively small cohorts of usually less than 100 cancer samples thus far. For example, the strong associations between IMP3 expression and advanced stage and grade in urinary bladder cancers and esophageal adenocarcinomas, or a squamous cell phenotype in lung cancers are in line with previous work on 76-384 cancers of the urinary bladder (23,24), 147 esophageal cancers (46) and 89-224 lung cancers (reviewed in refs. 47,48). Furthermore, the adverse prognostic impact of IMP3 expression in lung adenocarcinomas, pancreatic cancers and stomach cancers in our study were supported by previous studies on 40-190 patients in 
these types of cancer $(10,11,48-50)$. In addition a recent metaanalysis revealed a hazard ratio of 2.08 for decreased survival in solid tumors expressing high levels of IMP3 (51).

Our analysis provides a comprehensive overview on IMP3 protein expression in neoplastic human tissues. Tissue microarrays are an ideal tool to massively accelerate characterization of novel biomarkers. The use of TMAs to jointly screen many different tumor types for molecular alterations of interest is an obvious application of this technique. In earlier studies we had used multi-tumor TMAs for the evaluation of cyclin E (52), calretinin (53), KIT (54), ERG (55) or copy number changes of 17q23 (56). Others have used comparable TMAs to evaluate SPANX-B (57), SIL (58), NOX1 (59), COX2, MMP2, or MMP9 (60).

It is a distinct advantage of the TMA technique that all tissues are analyzed under maximally standardized conditions. While automated immunostainers, despite some remaining day-to-day variability, can provide good standardization of the staining process, TMAs enable a control of several additional important parameters affecting immunostaining. For example, TMAs overcome the issue of slide ageing and decreased immunoreactivity (61) that can become a serious problem in conventional large studies where tissue sections are often stored over a longer period of time prior to analysis, because all tissue samples in a TMA can be easily sectioned and stained within one day.

In summary, the results of our study show that IMP3 expression is a common feature of most human solid cancer types, but may also be observed in benign lesions. Strong IMP3 expression is often linked to adverse tumor features.

\section{Acknowledgements}

We would like to thank Christina Koop, Julia Schumann, Sünje Seekamp, and Inge Brandt for excellent technical assistance.

\section{References}

1. Gong Y, Woda BA and Jiang Z: Oncofetal protein IMP3, a new cancer biomarker. Adv Anat Pathol 21: 191-200, 2014.

2. Vikesaa J, Hansen TV, Jønson L, Borup R, Wewer UM, Christiansen J and Nielsen FC: RNA-binding IMPs promote cell adhesion and invadopodia formation. EMBO J 25: 1456-1468, 2006.

3. Xu H, Bourne PA, Spaulding BO and Wang HL: High-grade neuroendocrine carcinomas of the lung express $\mathrm{K}$ homology domain containing protein overexpressed in cancer but carcinoid tumors do not. Hum Pathol 38: 555-563, 2007.

4. Goodman S, Zhang L, Cheng L and Jiang Z: Differential expression of IMP3 between male and female mature teratomas - immunohistochemical evidence of malignant nature. Histopathology 65: 483-489, 2014.

5. Li D, Yan D, Tang H, Zhou C, Fan J, Li S, Wang X, Xia J, Huang F, Qiu G, et al: IMP3 is a novel prognostic marker that correlates with colon cancer progression and pathogenesis. Ann Surg Oncol 16: 3499-3506, 2009.

6. Lok T, Chen L, Lin F and Wang HL: Immunohistochemical distinction between intrahepatic cholangiocarcinoma and pancreatic ductal adenocarcinoma. Hum Pathol 45: 394-400, 2014.

7. Damasceno EA, Carneiro FP, Magalhães AV, Carneiro MV, Takano GH, Vianna LM, Seidler HB, Castro TM, MunizJunqueira MI, Amorim RF, et al: IMP3 expression in gastric cancer: Association with clinicopathological features and HER2 status. J Cancer Res Clin Oncol 140: 2163-2168, 2014
8. Jeng YM, Chang CC, Hu FC, Chou HY, Kao HL, Wang TH and Hsu HC: RNA-binding protein insulin-like growth factor II mRNA-binding protein 3 expression promotes tumor invasion and predicts early recurrence and poor prognosis in hepatocellular carcinoma. Hepatology 48: 1118-1127, 2008.

9. Jiang Z, Lohse CM, Chu PG, Wu CL, Woda BA, Rock KL and Kwon ED: Oncofetal protein IMP3: A novel molecular marker that predicts metastasis of papillary and chromophobe renal cell carcinomas. Cancer 112: 2676-2682, 2008.

10. Yan J, Wei Q, Jian W, Qiu B, Wen J, Liu J, Fu B, Zhou X and Zhao T: IMP3 predicts invasion and prognosis in human lung adenocarcinoma. Lung 194: 137-146, 2016.

11. Schaeffer DF, Owen DR, Lim HJ, Buczkowski AK, Chung SW, Scudamore $\mathrm{CH}$, Huntsman DG, Ng SS and Owen DA: Insulin-like growth factor $2 \mathrm{mRNA}$ binding protein 3 (IGF2BP3) overexpression in pancreatic ductal adenocarcinoma correlates with poor survival. BMC Cancer 10: 59, 2010.

12. Jiang Z, Chu PG, Woda BA, Rock KL, Liu Q, Hsieh CC, Li C, Chen W, Duan HO, McDougal S, et al: Analysis of RNA-binding protein IMP3 to predict metastasis and prognosis of renal-cell carcinoma: A retrospective study. Lancet Oncol 7: 556-564, 2006.

13. Tosun Yildirim H and Sentürk N: Analysis of IMP3 expression in prostate adenocarcinomas. Turk Patoloji Derg 28: 128-133, 2012.

14. Chromecki TF, Cha EK, Pummer K, Scherr DS, Tewari AK, Sun M, Fajkovic H, Roehrborn CG, Ashfaq R, Karakiewicz PI, et al: Prognostic value of insulin-like growth factor II mRNA binding protein 3 in patients treated with radical prostatectomy. BJU Int 110: 63-68, 2012.

15. Ikenberg K, Fritzsche FR, Zuerrer-Haerdi U, Hofmann I, Hermanns T, Seifert H, Müntener M, Provenzano M, Sulser T, Behnke S, et al: Insulin-like growth factor II mRNA binding protein 3 (IMP3) is overexpressed in prostate cancer and correlates with higher Gleason scores. BMC Cancer 10: 341, 2010.

16. Szarvas T, Tschirdewahn S, Niedworok C, Kramer G, Sevcenco S, Reis H, Shariat SF, Rübben H and vom Dorp F: Prognostic value of tissue and circulating levels of IMP3 in prostate cancer. Int J Cancer 135: 1596-1604, 2014.

17. Kulaçoğlu S and Erkılınç G: Imp3 expression in benign and malignant thyroid tumors and hyperplastic nodules. Balkan Med J 32: 30-37, 2015 .

18. Slosar M, Vohra P, Prasad M, Fischer A, Quinlan R and Khan A: Insulin-like growth factor mRNA binding protein 3 (IMP3) is differentially expressed in benign and malignant follicular patterned thyroid tumors. Endocr Pathol 20: 149-157, 2009.

19. Yorukoglu A, Yalcin N, Avci A, Cakalagaoglu F, Yaylali G, Akin F, Haciyanli M and Ozden A: Significance of IMP3, nucleophosmin, and $\mathrm{Ki}-67$ expression in papillary thyroid carcinoma. Int J Surg Pathol 23: 5-12, 2015.

20. Jin L, Seys AR, Zhang S, Erickson-Johnson MR, Roth CW, Evers BR, Oliveira AM and Lloyd RV: Diagnostic utility of IMP3 expression in thyroid neoplasms: A quantitative RT-PCR study. Diagn Mol Pathol 19: 63-69, 2010.

21. Yamamoto H, Arakaki K, Morimatsu K, Zaitsu Y, Fujita A, Kohashi K, Hirahashi M, Motoshita J, Oshiro Y and Oda Y: Insulin-like growth factor II messenger RNA-binding protein 3 expression in gastrointestinal mesenchymal tumors. Hum Pathol 45: 481-487, 2014.

22. Cornejo K, Shi M and Jiang Z: Oncofetal protein IMP3: A useful diagnostic biomarker for leiomyosarcoma. Hum Pathol 43: 1567-1572, 2012.

23. Lee DJ, Xylinas E, Rieken M, Khani F, Klatte T, Wood CG, Karam JA, Weizer AZ, Raman JD, Remzi M, et al: Insulin-like growth factor messenger RNA-binding protein 3 expression helps prognostication in patients with upper tract urothelial carcinoma. Eur Urol 66: 379-385, 2014

24. Xylinas E, Cha EK, Khani F, Kluth LA, Rieken M, Volkmer BG, Hautmann R, Küfer R, Chen YT, Zerbib M, et al: Association of oncofetal protein expression with clinical outcomes in patients with urothelial carcinoma of the bladder. J Urol 191: 830-841, 2014.

25. Del Gobbo A, Vaira V, Guerini Rocco E, Palleschi A, Bulfamante G, Ricca D, Fiori S, Bosari S and Ferrero S: The oncofetal protein IMP3: A useful marker to predict poor clinical outcome in neuroendocrine tumors of the lung. J Thorac Oncol 9: 1656-1661, 2014

26. Chang S, Oh MH, Ji SY, Han J, Kim TJ, Eom M, Kwon KY, Ha SY, Choi YD, Lee CH, et al: Practical utility of insulin-like growth factor II mRNA-binding protein 3 , glucose transporter 1 , and epithelial membrane antigen for distinguishing malignant mesotheliomas from benign mesothelial proliferations. Pathol Int 64: 607-612, 2014. 
27. Ücer Ö, Dağli AF, Kiliçarslan A and Artas G: Value of Glut-1 and Koc markers in the differential diagnosis of reactive mesothelial hyperplasia, malignant mesothelioma and pulmonary adenocarcinoma. Turk Patoloji Derg 29: 94-100, 2013.

28. Kononen J, Bubendorf L, Kallioniemi A, Bärlund M, Schraml P, Leighton S, Torhorst J, Mihatsch MJ, Sauter G and Kallioniemi OP: Tissue microarrays for high-throughput molecular profiling of tumor specimens. Nat Med 4: 844-847, 1998.

29. Steurer S, Singer JM, Rink M, Chun F, Dahlem R, Simon R, Burandt E, Stahl P, Terracciano L, Schlomm T, et al: MALDI imaging-based identification of prognostically relevant signals in bladder cancer using large-scale tissue microarrays. Urol Oncol 32: 1225-1233, 2014.

30. von Loga K, Kohlhaussen J, Burkhardt L, Simon R, Steurer S, Burdak-Rothkamm S, Jacobsen F, Sauter G and Krech T: FGFR1 amplification is often homogeneous and strongly linked to the squamous cell carcinoma subtype in esophageal carcinoma. PLoS One 10: e0141867, 2015.

31. Grob TJ, Kannengiesser I, Tsourlakis MC, Atanackovic D, Koenig AM, Vashist YK, Klose H, Marx AH, Koops S, Simon R, et al: Heterogeneity of ERBB2 amplification in adenocarcinoma, squamous cell carcinoma and large cell undifferentiated carcinoma of the lung. Mod Pathol 25: 1566-1573, 2012.

32. Gebauer F, Tachezy M, Effenberger K, von Loga K, Zander H, Marx A, Kaifi JT, Sauter G, Izbicki JR and Bockhorn M: Prognostic impact of CXCR4 and CXCR7 expression in pancreatic adenocarcinoma. J Surg Oncol 104: 140-145, 2011

33. Mina S, Bohn BA, Simon R, Krohn A, Reeh M, Arnold D, Bokemeyer C, Sauter G, Izbicki JR, Marx A, et al: PTEN deletion is rare but often homogeneous in gastric cancer. J Clin Pathol 65 693-698, 2012.

34. Hammer NA, Hansen T, Byskov AG, Rajpert-De Meyts E, Grøndahl ML, Bredkjaer HE, Wewer UM, Christiansen J and Nielsen FC: Expression of IGF-II mRNA-binding proteins (IMPs) in gonads and testicular cancer. Reproduction 130: 203-212, 2005.

35. Tang H, Wei Q, Ge J, Jian W, Liu J, Zhong L, Fu B and Zhao T: IMP3 as a supplemental diagnostic marker for Hodgkin lymphoma. Hum Pathol 44: 2167-2172, 2013.

36. Pryor JG, Simon RA, Bourne PA, Spaulding BO, Scott GA and $\mathrm{Xu} \mathrm{H}$ : Merkel cell carcinoma expresses $\mathrm{K}$ homology domain-containing protein overexpressed in cancer similar to other high-grade neuroendocrine carcinomas. Hum Pathol 40 238-243, 2009

37. Vranic S, Gurjeva O, Frkovic-Grazio S, Palazzo J, Tawfik O and Gatalica Z: IMP3, a proposed novel basal phenotype marker, is commonly overexpressed in adenoid cystic carcinomas but not in apocrine carcinomas of the breast. Appl Immunohistochem Mol Morphol 19: 413-416, 2011.

38. Chokoeva AA, Ananiev J, Wollina U, Tana C, Lotti T, Cardoso JC and Tchernev G: Imp-3 expression in benign melanocytic nevi, dysplastic nevi and malignant melanoma: preliminary findings in Bulgarian patients. J Biol Regul Homeost Agents 29: 695-699, 2015.

39. Shooshtarizadeh T, Nazeri A,Zare-Mirzaie A and Movahedinia S Expression of insulin-like growth factor II mRNA binding protein 3 (IMP3) in enchondroma and chondrosarcoma. Pathol Res Pract 212: 335-339, 2016

40. Lee AF, Gown AM and Churg A: IMP3 and GLUT-1 immunohistochemistry for distinguishing benign from malignant mesothelial proliferations. Am J Surg Pathol 37: 421-426, 2013.

41. Ikeda K, Tate G, Suzuki T, Kitamura T and Mitsuya T: IMP3/ L523S, a novel immunocytochemical marker that distinguishes benign and malignant cells: The expression profiles of IMP3/ L523S in effusion cytology. Hum Pathol 41: 745-750, 2010.

42. Pryor JG, Bourne PA, Yang Q, Spaulding BO, Scott GA and Xu H: IMP-3 is a novel progression marker in malignant melanoma. Mod Pathol 21: 431-437, 2008

43. Yantiss RK, Woda BA, Fanger GR, Kalos M, Whalen GF, Tada H, Andersen DK, Rock KL and Dresser K: KOC (K homology domain containing protein overexpressed in cancer): A novel molecular marker that distinguishes between benign and malignant lesions of the pancreas. Am J Surg Pathol 29: 188-195, 2005 .

44. Nielsen J, Christiansen J, Lykke-Andersen J, Johnsen AH, Wewer UM and Nielsen FC: A family of insulin-like growth factor II mRNA-binding proteins represses translation in late development. Mol Cell Biol 19: 1262-1270, 1999.
45. Mueller-Pillasch F, Pohl B, Wilda M, Lacher U, Beil M, Wallrapp C, Hameister H, Knöchel W, Adler G and Gress TM: Expression of the highly conserved RNA binding protein KOC in embryogenesis. Mech Dev 88: 95-99, 1999.

46. Lu D, Vohra P, Chu PG, Woda B, Rock KL and Jiang Z: An oncofetal protein IMP3: A new molecular marker for the detection of esophageal adenocarcinoma and high-grade dysplasia. Am J Surg Pathol 33: 521-525, 2009.

47. Szarvas T, vom Dorp F, Niedworok C, Melchior-Becker A, Fischer JW, Singer BB, Reis H, Bánkfalvi Á, Schmid KW, Romics I, et al: High insulin-like growth factor mRNA-binding protein 3 (IMP3) protein expression is associated with poor survival in muscle-invasive bladder cancer. BJU Int 110 E308-E317, 2012

48. Findeis-Hosey JJ and $\mathrm{Xu} \mathrm{H}$ : Insulin-like growth factor II-messenger RNA-binding protein-3 and lung cancer. Biotech Histochem 87: 24-29, 2012.

49. Wang L, Li HG, Xia ZS, Lü J and Peng TS: IMP3 is a novel biomarker to predict metastasis and prognosis of gastric adenocarcinoma: A retrospective study. Chin Med J (Engl) 123: 3554-3558, 2010

50. Morimatsu K, Aishima S, Yamamoto H, Hayashi A, Nakata K, Oda Y, Shindo K, Fujino M, Tanaka M and Oda Y: Insulin-like growth factor II messenger RNA-binding protein-3 is a valuable diagnostic and prognostic marker of intraductal papillary mucinous neoplasm. Hum Pathol 44: 1714-1721, 2013.

51. Chen L, Xie Y, Li X, Gu L, Gao Y, Tang L, Chen J and Zhang X: Prognostic value of high IMP3 expression in solid tumors: A meta-analysis. Onco Targets Ther 10: 2849-2863, 2017.

52. Schraml P, Bucher C, Bissig H, Nocito A, Haas P, Wilber K, Seelig S, Kononen J, Mihatsch MJ, Dirnhofer S, et al: Cyclin E overexpression and amplification in human tumours. J Pathol 200: 375-382, 2003

53. Lugli A, Forster Y, Haas P, Nocito A, Bucher C, Bissig H, Mirlacher M, Storz M, Mihatsch MJ and Sauter G: Calretinin expression in human normal and neoplastic tissues: A tissue microarray analysis on 5233 tissue samples. Hum Pathol 34: 994-1000, 2003.

54. Went PT, Dirnhofer S, Bundi M, Mirlacher M, Schraml P, Mangialaio S, Dimitrijevic S, Kononen J, Lugli A, Simon R, et al: Prevalence of KIT expression in human tumors. J Clin Oncol 22: 4514-4522, 2004

55. Minner S, Luebke AM, Kluth M, Bokemeyer C, Jänicke F, Izbicki J, Schlomm T, Sauter G and Wilczak W: High level of Ets-related gene expression has high specificity for prostate cancer: A tissue microarray study of 11483 cancers. Histopathology 61: 445-453, 2012.

56. Andersen CL, Monni O, Wagner U, Kononen J, Bärlund M, Bucher C, Haas P, Nocito A, Bissig H, Sauter G, et al: Highthroughput copy number analysis of $17 \mathrm{q} 23$ in 3520 tissue specimens by fluorescence in situ hybridization to tissue microarrays. Am J Pathol 161: 73-79, 2002.

57. Almanzar G, Olkhanud PB, Bodogai M, Dell'agnola C, Baatar D, Hewitt SM, Ghimenton C, Tummala MK, Weeraratna AT, Hoek KS, et al: Sperm-derived SPANX-B is a clinically relevant tumor antigen that is expressed in human tumors and readily recognized by human $\mathrm{CD}^{+}$and $\mathrm{CD} 8^{+} \mathrm{T}$ cells. Clin Cancer Res 15: 1954-1963, 2009.

58. Erez A, Perelman M, Hewitt SM, Cojacaru G, Goldberg I, Shahar I, Yaron P, Muler I, Campaner S, Amariglio N, et al: Sil overexpression in lung cancer characterizes tumors with increased mitotic activity. Oncogene 23: 5371-5377, 2004.

59. Geiszt M, Lekstrom K, Brenner S, Hewitt SM, Dana R, Malech HL and Leto TL: NAD(P)H oxidase 1, a product of differentiated colon epithelial cells, can partially replace glycoprotein 91phox in the regulated production of superoxide by phagocytes. J Immunol 171: 299-306, 2003.

60. Dicken BJ, Graham K, Hamilton SM, Andrews S, Lai R, Listgarten J, Jhangri GS, Saunders LD, Damaraju S and Cass C: Lymphovascular invasion is associated with poor survival in gastric cancer: An application of gene-expression and tissue array techniques. Ann Surg 243: 64-73, 2006.

61. Mirlacher M, Kasper M, Storz M, Knecht Y, Dürmüller U, Simon R, Mihatsch MJ and Sauter G: Influence of slide aging on results of translational research studies using immunohistochemistry. Mod Pathol 17: 1414-1420, 2004

62. Mhawech-Fauceglia P, Herrmann FR, Rai H, Tchabo N, Lele S, Izevbaye I, Odunsi K and Cheney RT: IMP3 distinguishes uterine serous carcinoma from endometrial endometrioid adenocarcinoma. Am J Clin Pathol 133: 899-908, 2010. 
63. Zheng W, Yi X, Fadare O, Liang SX, Martel M, Schwartz PE and Jiang Z: The oncofetal protein IMP3: A novel biomarker for endometrial serous carcinoma. Am J Surg Pathol 32: 304-315, 2008.

64. Yi X and Zheng W: Endometrial glandular dysplasia and endometrial intraepithelial neoplasia. Curr Opin Obstet Gynecol 20: 20-25, 2008.

65. Li C, Zota V, Woda BA, Rock KL, Fraire AE, Jiang Z, Lu D, Xu B, Dresser K, Lutman CV, et al: Expression of a novel oncofetal mRNA-binding protein IMP3 in endometrial carcinomas: Diagnostic significance and clinicopathologic correlations. Mod Pathol 20: 1263-1268, 2007.

66. Kazeminezhad B, Mirafsharieh SA, Dinyari K, Azizi D and Ebrahimi A: Usefulness of insulin-like growth factor II mRNAbinding protein 3 (IMP3) as a new marker for the diagnosis of esophageal adenocarcinoma in challenging cases. Turk J Gastroenterol 25: 253-256, 2014.

67. Feng W, Zhou Z, Peters JH, Khoury T, Zhai Q, Wei Q, Truong CD, Song SW and Tan D: Expression of insulin-like growth factor II mRNA-binding protein 3 in human esophageal adenocarcinoma and its precursor lesions. Arch Pathol Lab Med 135: 1024-1031, 2011.

68. He Y, Li L, Jiang W, Wang DQ, Xu L, Huang Q, Zhang Y and Yang KX: Expression of the insulin-like growth factor-II mRNAbinding protein 3 (IMP3) and carcinoembryonic antigen (CEA) in mucinous minimal deviation adenocarcinoma. Pathol Res Pract 207: 295-299, 2011

69. Wachter DL, Schlabrakowski A, Hoegel J, Kristiansen G, Hartmann A and Riener MO: Diagnostic value of immunohistochemical IMP3 expression in core needle biopsies of pancreatic ductal adenocarcinoma. Am J Surg Pathol 35: 873-877, 2011

70. Lin L, Zhang J, Wang Y, Zheng L, Lin Z and Cai Y: Expression of insulin-like growth factor 2 mRNA-binding protein 3 expression and analysis of prognosis in the patients with lung squamous cell carcinoma. Xi Bao Yu Fen Zi Mian Yi Xue Za Zhi 29: 694-697, 2013 (In Chinese)

71. Beljan Perak R, Durdov MG, Capkun V, Ivcevic V, Pavlovic A, Soljic V and Peric M: IMP3 can predict aggressive behaviour of lung adenocarcinoma. Diagn Pathol 7: 165, 2012.

72. Findeis-Hosey JJ, Yang Q, Spaulding BO, Wang HL and Xu H: IMP3 expression is correlated with histologic grade of lung adenocarcinoma. Hum Pathol 41: 477-484, 2010

73. Chen ST, Jeng YM, Chang CC, Chang HH, Huang MC, Juan HF, Hsu CH, Lee H, Liao YF, Lee YL, et al: Insulin-like growth factor II mRNA-binding protein 3 expression predicts unfavorable prognosis in patients with neuroblastoma. Cancer Sci 102: 2191-2198, 2011.

74. Takata A, Takiguchi S, Okada K, Takahashi T, Kurokawa Y, Yamasaki M, Miyata H, Nakajima K, Mori M and Doki Y: Expression of insulin-like growth factor-II mRNA-binding protein-3 as a marker for predicting clinical outcome in patients with esophageal squamous cell carcinoma. Oncol Lett 8: 2027-2031, 2014

75. King RL, Pasha T, Roullet MR, Zhang PJ and Bagg A: IMP-3 is differentially expressed in normal and neoplastic lymphoid tissue. Hum Pathol 40: 1699-1705, 2009.

76. Gaete S: Consciousness as meaning. Actas Luso Esp Neurol Psiquiatr 28: 306-330, 1969 (In Spanish).

77. Minato H, Kurose N, Fukushima M, Nojima T, Usuda K, Sagawa M, Sakuma T, Ooi A, Matsumoto I, Oda M, et al: Comparative immunohistochemical analysis of IMP3, GLUT1, EMA, CD146, and desmin for distinguishing malignant mesothelioma from reactive mesothelial cells. Am J Clin Pathol 141: 85-93, 2014.

78. Shi J, Liu H, Wang HL, Prichard JW and Lin F: Diagnostic utility of von Hippel-Lindau gene product, maspin, IMP3, and S100P in adenocarcinoma of the gallbladder. Hum Pathol 44: 503-511, 2013.

79. Yu L, Xu H, Wasco MJ, Bourne PA and Ma L: IMP-3 expression in melanocytic lesions. J Cutan Pathol 37: 316-322, 2010.

80. Elshafey MR, Ahmed RA, Mourad MI and Gaballah ET: The oncofetal protein IMP3 is an indicator of early recurrence and poor outcome in mucoepidermoid carcinoma of salivary glands. Cancer Biol Med 13: 286-295, 2016.
81. Ismerim AB, Ferreira SV, Lessa AM, Pereira Júnior AS, Gurgel CA, Coutinho-Camillo CM, Soares FA, Vilas-Bôas DS, Vidal MT and Santos JN: Insulin-like growth factor ii messenger RNA-binding protein 3 in salivary gland tumors. Appl Immunohistochem Mol Morphol 24: 422-426, 2016.

82. Chisté M, Alexis J and Recine M: IMP3 expression in serous tumors of the ovary. Appl Immunohistochem Mol Morphol 22: 658-662, 2014

83. Hu S, Wu X, Zhou B, Xu Z, Qin J, Lu H, Lv L, Gao Y, Deng L, Yin J, et al: IMP3 combined with CD44s, a novel predictor for prognosis of patients with hepatocellular carcinoma. J Cancer Res Clin Oncol 140: 883-893, 2014.

84. Wachter DL, Kristiansen G, Soll C, Hellerbrand C, Breuhahn K, Fritzsche F, Agaimy A, Hartmann A and Riener MO: Insulin-like growth factor II mRNA-binding protein 3 (IMP3) expression in hepatocellular carcinoma. A clinicopathological analysis with emphasis on diagnostic value. Histopathology 60: 278-286, 2012.

85. Soddu S, Di Felice E, Cabras S, Castellanos ME, Atzori L, Faa G and Pilloni L: IMP-3 expression in keratoacanthomas and squamous cell carcinomas of the skin: An immunohistochemical study. Eur J Histochem 57: e6, 2013.

86. Denby KS, Briones AJ, Bourne PA, Spaulding BO, Lu D, Fischer-Colbrie R, Qu Z, Wang HL and Xu H: IMP3, NESP55, TTF-1 and CDX2 serve as an immunohistochemical panel in the distinction among small-cell carcinoma, gastrointestinal carcinoid, and pancreatic endocrine tumor metastasized to the liver. Appl Immunohistochem Mol Morphol 20: 573-579, 2012.

87. Li C, Rock KL, Woda BA, Jiang Z, Fraire AE and Dresser K IMP3 is a novel biomarker for adenocarcinoma in situ of the uterine cervix: An immunohistochemical study in comparison with p16(INK4a) expression. Mod Pathol 20: 242-247, 2007.

88. Shantha Kumara H, Kirchoff D, Caballero OL, Su T, Ahmed A, Herath SA, Njoh L, Cekic V, Simpson AJ, Cordon-Cardo C, et al: Expression of the cancer testis antigen IGF2BP3 in colorectal cancers; IGF2BP3 holds promise as a specific immunotherapy target. Oncoscience 2: 607-614, 2015.

89. Lochhead P, Imamura Y, Morikawa T, Kuchiba A, Yamauchi M, Liao X, Qian ZR, Nishihara R, Wu K, Meyerhardt JA, et al: Insulin-like growth factor 2 messenger RNA binding protein 3 (IGF2BP3) is a marker of unfavourable prognosis in colorectal cancer. Eur J Cancer 48: 3405-3413, 2012.

90. Liu W, Wang P, Li Z, Xu W, Dai L, Wang K and Zhang J: Evaluation of tumour-associated antigen (TAA) miniarray in immunodiagnosis of colon cancer. Scand J Immunol 69: 57-63, 2009.

91. Barton VN, Donson AM, Birks DK, Kleinschmidt-DeMasters BK, Handler MH, Foreman NK and Rush SZ: Insulin-like growth factor 2 mRNA binding protein 3 expression is an independent prognostic factor in pediatric pilocytic and pilomyxoid astrocytoma. J Neuropathol Exp Neurol 72: 442-449, 2013.

92. Bellezza G, Prosperi E, Del Sordo R, Colella R, Rulli A and Sidoni A: IMP3 is strongly expressed in malignant phyllodes tumors of the breast: An immunohistochemical study. Int J Surg Pathol 24: 37-42, 2016.

93. Walter O, Prasad M, Lu S, Quinlan RM, Edmiston KL and Khan A: IMP3 is a novel biomarker for triple negative invasive mammary carcinoma associated with a more aggressive phenotype. Hum Pathol 40: 1528-1533, 2009.

94. Hoffmann NE, Sheinin Y, Lohse CM, Parker AS, Leibovich BC, Jiang $\mathrm{Z}$ and Kwon ED: External validation of IMP3 expression as an independent prognostic marker for metastatic progression and death for patients with clear cell renal cell carcinoma. Cancer 112: 1471-1479, 2008

95. Sitnikova L, Mendese G, Liu Q, Woda BA, Lu D, Dresser K, Mohanty S, Rock KL and Jiang Z: IMP3 predicts aggressive superficial urothelial carcinoma of the bladder. Clin Cancer Res 14: 1701-1706, 2008.

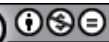

This work is licensed under a Creative Commons Attribution-NonCommercial-NoDerivatives 4.0 International (CC BY-NC-ND 4.0) License. 